\title{
Raising of quality saplings of arid horticultural crops: a review
}

\section{DK Sarolia, RK Meena, KL Kumawat, MK Choudhary \& DK Singh}

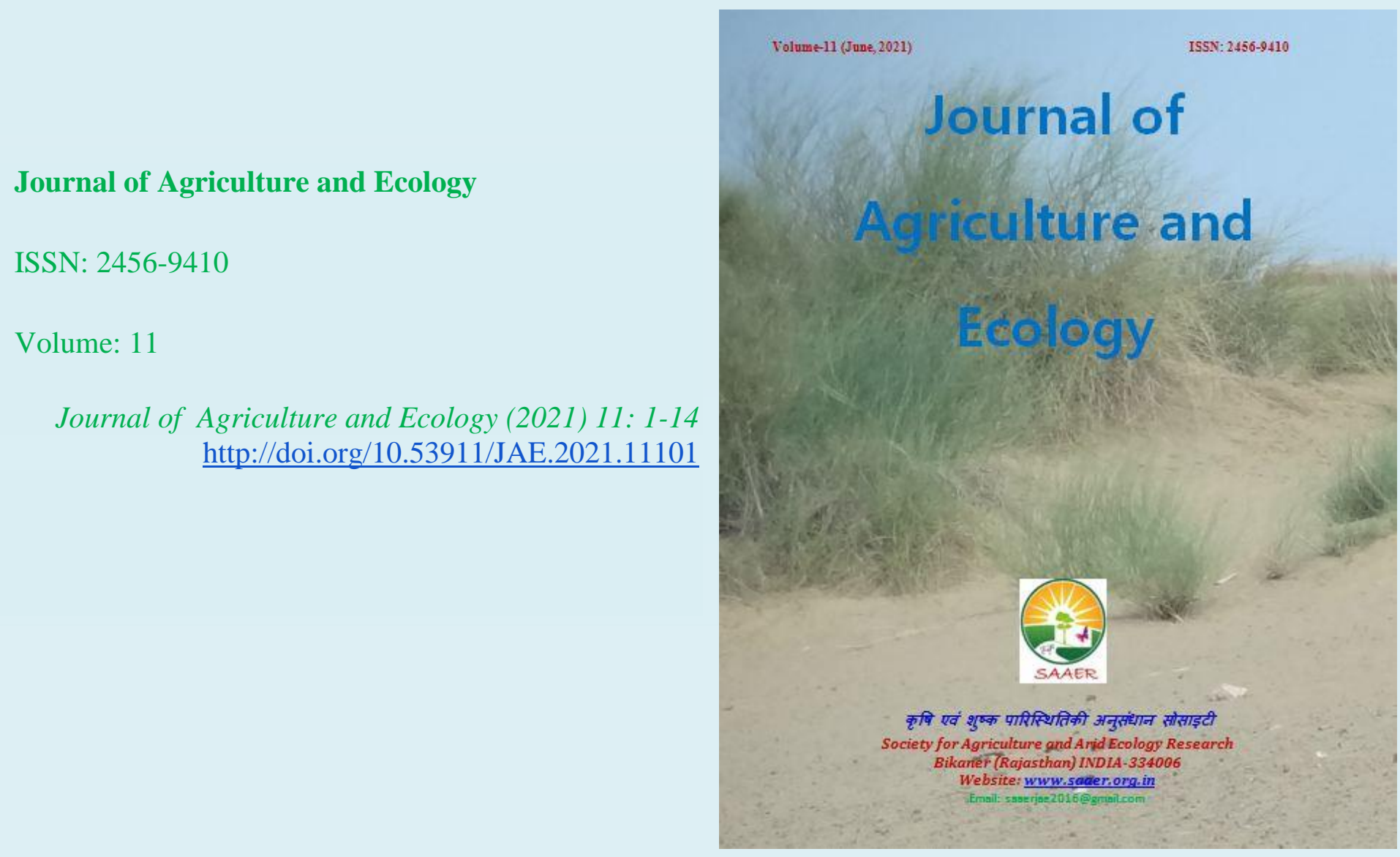




\section{Raising of quality saplings of arid horticultural crops: a review}

DK Sarolia $\not$, RK Meena, KL Kumawat, MK Choudhary \& DK Singh*

ICAR-Central Institute for Arid Horticulture, Bikaner - 334006 (Rajasthan)

* Department of Horticulture, Kulbhakar Ashram PG College Prayagraj-211001

$\square$ Corresponding author: DK Sarolia, E-mail:deephorti@gmail.com

Article Info

Article history

Received: 20 May 2021

Accepted: 25 June 2021

Available online: 30 June 2021

Key Words: Saplings, quality, planting material, arid horticulture.

\begin{abstract}
Planting material includes the parts of plants used for reproduction sexual or asexual ways may be seed, bulbs, sucker, offshoot, tuber, slip, corm or other plant parts. Mass level production of saplings requires standard propagation techniques depending upon the kind of crops, conditions (lab or open), climatic region (humid or arid) etc. Arid region where the paucity of water and in open nursery condition a short span is available for propagation activities and growth of the saplings while, in modern nursery unit equipped with advance structures (net house, shed net at varying intensity, mist chamber, lath house, propagation case, humidity chamber, fluorescent box, hardening chamber, mini greenhouse etc.) such activities may be performed round the year and multiplication of plant is possible. So both the ways utilize nursery unit as multiplication of saplings in mass scale as well as conservation of exotic or extra care requiring saplings may be seedlings, rootstocks, cuttage, layers, grafts, micropropagated plantlets till the transplanting at field. Standards have been set for seed (appearance, purity per cent, inert material status, weed seed count, germination status, vigour etc.), seedlings (uniformity, vigourness, growth, survivality, susceptibility to disease and pests, moisture content, size, age weight etc.) and varietal (purity, genuineness, free from stresses, health, authenticity etc.) quality. Production of saplings in arid region requires more attention to take up timely action so that farmers may get quality planting materials at the proper time and at the same time, the producer may gain the desired returns.
\end{abstract}

Copyright (C2021 Sarolia et al., This is an open access article published under the terms of the Creative Commons Attribution License, which permits unrestricted use, distribution, and reproduction in any medium, provided the original work is properly cited.

Preferred citation: Sarolia DK, Meena RK, Kumawat KL, Choudhary MK \& Singh DK. 2021. Raising of quality saplings of arid horticultural crops: a review. Journal of Agriculture and Ecology, 11: 1-14; http://doi.org/10.53911/JAE.2021.11101.

\section{Introduction}

Inadequate availability of quality planting materials is an important deterring factor in the development of the sound horticulture industry. In the horticulture of the arid region major portion is covered by fruits and vegetables. During the past decade, significant achievements have been made for fruit and vegetable development and an area 
of 15.97 million hectares has been brought under both the crops that cover about 67.15 and $90 \%$ of total horticulture area and production, respectively (Anonymous 2021). The impact of investments in horticultural research can be realized only if farmers have better access to high quality planting materials of the improved varieties at reasonable costs and at their production sites. Use of quality planting material of horticultural commodities of the recommended zones can ensure higher productivity and easy availability of the produce. In recent past, a good number of crop genotype suited to hot arid agro-climate has been developed. However, the availability of their planting materials is still in short supply. Government agencies through their network on planting material production have intensified the work on production of planting material. Although, the existing infrastructure facilities fulfill about 30-40 per cent of supply, therefore need to strengthen it, so that the developed technologies can be commercialized for enhancing the production level (Sarolia et al. 2018; Singh \& More 2008).

Systematic crop production is limited in the hot arid region of the north-western part of India and this is mainly due to the unavailability of desirable crop-genotypes, planting material and technologies suited to the prevailing agro-climatic conditions. In the nursery, one can carry out the following activities (Ratha et al. 2014):

- Plant seedlings preparation

- Raise rootstocks

- Multiply improved varieties

- Grafting and budding operations

- Take care of delicate fruit tree seedlings
- Multiply rare types of fruit trees

- Conserve the plants as per their requirement

- Generate income on a small plot

\section{Component wise management strategies}

1. Site and structures for nursery raising: Plant multiplication in nursery generally through two techniques as conventional and modern. The conventional method following protocol is mainly adopted (Anonymous 2009) as: i) Nursery beds of well pulverized soil with $3 \mathrm{~m} \times 1 \mathrm{~m} \times 0.15 \mathrm{~m}$ size are prepared. ii) The beds are fertilized with 20 to $25 \mathrm{~kg}$ well rotten FYM, $200 \mathrm{~g}$ SSP and 15-20 g dithane M-45. iii) To prevent soil born disease, nursery beds are treated with formaldehyde (25 $\mathrm{ml} /$ litre of water) and are covered with airtight polythene for one week and after removing the polythene the soil is turned up and down for three weeks to remove the remains of the formalin fumes. iv) Pre treatment of seed with carbendazim or copper oxi chloride (2 $-3 \mathrm{~g} / \mathrm{kg}$ of seed) is also practiced to check the attack of seed/soil born fungus. v) The treated seeds are sown in the lines $5 \mathrm{~cm}$ apart at $0.5-1.0 \mathrm{~cm}$ depth and are covered with thin layer of well rotten FYM and soil mixture. vi)In order to conserve soil moisture, beds are mulched with dry grass and are irrigated in morning and evening hours regularly till the seedlings emerge out. vii) Mulched grass is removed as soon as the seedling emergence is observed and nursery beds are drenched with a mixture of dithane M-45 (0.25\%) and carbendazim $(0.1 \%)$ to avoid damping-off disease. viii)In case seedlings are weak/deficient in nitrogen, urea is sprayed @ 0.3\% when seedlings are 8-10 $\mathrm{cm}$ tall. ix) The seedlings become ready for 
transplanting in 4-6 weeks or when they attain a height of $10-15 \mathrm{~cm} . \mathrm{x}$ ) Irrigation is withheld 3-4 days prior to transplanting so that plants become hardened (Mbora 2008). But, on the day of transplanting, sufficient water is applied in the nursery bed and then seedlings are taken out for transplanting. xi) The transplanting is mainly carried out during evening hours for better field establishment. In modern techniques advanced nursery structures using for raising of quality planting material describe as under (Bhardwaj \& Sarolia 2011; Sharma \& Srivastav 2004):

(i). Agro-Shade Houses: Shade houses in nurseries offer many advantages like raising of seedlings in bags directly, protecting the grafts from hot summer months, effective irrigation through upside down overhead micro sprinklers. The shade house made with shade nets $(50 \%$ or $75 \%)$ for regulation of shade is particularly very useful in arid regions where the humidity is very low during summer months.

(ii). Green Houses /Poly Houses: Grafting or budding of several fruit species under poly house or low cost green houses with natural ventilation will enhance the percentage graft / bud take besides faster growth of grafts due to favorable micro climatic conditions of poly house. In green house construction a wood or metal frame work is built to which wood or metal sack bars are fixed to support panes of glass work. In all poly house/greenhouse means of providing air movement and air, exchange is necessary to aid in controlling temperature and humidity. It is the best, if possible to have in the green house heating and self -opening ventilators and evaporative cooling systems. Plastic covered green houses tend to be much lighter than glass covered once with a buildup of excessively humidity. (iii). Hotbeds: The hotbeds are often used for the same purpose as a green house but in a smaller scale. Amateur operations and seedling can be started and leafy cuttings root easily in the cold seasons in such structures. Heat is provided artificially below the propagating medium by electric heating cables, pot water, steam pipes or hot air blows. As in the green house, in the hot beds attention must be paid for shading and ventilation as well as temperature and humidity control.

(iv). Lath Houses: These structures are very useful in providing protection from the sun for container grown nursery stocks in areas of high summer temperatures and high light intensity. Well-established plants also require lath house protection including shade-loving plants. Lath house construction varies widely depending on the material used. Aluminum pre-fabricated lath house are available but may be more costly than wood structures. Shade is provided by appropriate structures and the use of shade nets of different densities allows various intensities of light in the lath house.

(v). Mist Chambers: This is a structure used to propagate soft wood cutting, difficult to root plants and shrubs. Here the principle is to spray the cutting with a minimum quantity of water. This is achieved by providing the cutting a series of intermittent spraying rather than a continuous spray. The intermitted spraying can be done easily by means of a high-pressure pump and a time switch, operating a magnetic solenoid valve and is set in a way to turn on the mist for 3-5 seconds to 
wet the leaves and turn off for some time and when the leaves are dry, the mist is again turned on. The pump leads to a pipeline system inside the propagating structure. The mist nozzles are fitted to these pipelines and suitability spaced over the propagating material. While installing mist propagation unit, all the jets should be at equal height. Further, it is essential that a well-drained rooting medium is used and there should be a proper provision for adequate removal of excess water. The water should have good pressure and it must be free from salts. The optimum $\mathrm{pH}$ of water to be used in mist unit is 5.5 to 6.5. Hard water or alkaline water may be avoided as it may block the nozzles of the mist chamber and it may accumulate on the young leaves of the cuttings and thus inhibit the growth and development of roots.

(vi). Miscellaneous Propagating Structures:

(a) Nursery Bed: These are raised beds or boxes made of bricks and mortar, provided with drainage holes at the bottom. The dimension of the boxes are $60 \mathrm{~cm}$ high, 120 $\mathrm{cm}$ broad and length as required preferably not exceeding $10 \mathrm{~m}$ roof structures for planting on both sides and forming ridges at the center are constructed on the top of the nursery beds. These structures may be made permanent with angle iron or may be made of wood. Bamboos mats, palm leaf mats are placed over these structures to protect the seedling from hot sun and heavy rains.

(b) Fluorescent Light Boxes: Young plants of many species grow satisfactory under artificial light from fluorescent lamp units. Although adequate growth of many plant species may be obtained under fluorescent lamps but not up to the mark compared to good green house conditions.

(c) Propagation Cases: Even in green house, humidity condition is often not sufficiently high for rooting. The use of enclosed frames or cases covered with glass or plastic materials may be necessary for successful rooting. In using such structures, care is necessary to avoid the buildup of disease organisms due to high humidity.

(d) Mini-Green Houses: The plants need carbon dioxide for making food through photosynthesis. The green house helps in providing additional carbon dioxide to the plants to enhance their rate of photosynthesis. This can be achieved by enclosing the plants in a box like structure made out of bamboo and colorless transparent plastic, with a lid at the top. The lid is closed after sun set, so that carbon dioxide produce due to respiration accumulate in the box. After sun rise the plant start photosynthesis and since there is higher carbon dioxide content around the plant, the rate of carbon assimilation is higher. After a few hours the lid is opened to prevent overheating alternatively. A plot or beds of plant can be provided with plastic films skirting supports by bamboo stakes, about $12 \mathrm{~cm}$. high. Since $\mathrm{CO}_{2}$ is heavier than air it tends to settle around the plants.

(e) Light Chamber: Several plants to go into winter dormancy when the day length shorts. Additional light from tube lights, given after sun-set, creates a long-day condition that prevents the plants from going into winter dormancy, light given at the end of the day. Also, encourage growth of green leaves; they grow tall without developing lateral branches. On the other hand, if they are exposed to 
fluorescent light from tube lights laid on the grounds, they developed side branches and show bushy habits.

(f) High-Humidity Chambers: This technique resolves the common problems of graft or cutting dying due to desiccation when planted in the soil for rooting, by ensuring a humid atmosphere around the cuttings, thus wood preventing excessive evaporation. The cutting/ grafts are planted on sand beds, enclosed on all the sides by a dome made of GI wire and covered with a transparent, colorless plastic film. The sand is watered to field capacity, and plastic film traps evaporation inside the chamber creating a highly humid atmosphere. The dome must be shaded, since direct sunlight will heat up the internal atmosphere of the dome, killing the plants.

(g) Cold frames: Relatively inexpensive structures, used for cool season crops during spring and fall and provide the sheltered location of plants from cold winds

2. Media for production of quality planting material

Successful nursery production of container-grown plants is largely dependent on the chemical and physical properties of the growing media. An ideal potting medium should be free of weeds and disease inoculums, heavy enough to avoid frequent tipping over and yet light enough to facilitate handling and shipping. The media should also be well drained and yet retain sufficient water to reduce the frequency of watering. Other parameters to consider include cost, availability, consistency between batches and stability in the media over time. The selection of the proper media components is critical to the successful production of plants (Surya 2012; Hartman et al. 2002).

3. Propagation techniques: Multiplication and perpetuation of the plants through standardized, commercial and advance methods of propagation depending on the basis of crop, region and technique(s) used for multiplying. In case of composite plants, rootstocks play an important role viz., citrus, bael, khejri, aonla ber, etc. For specific purposes e.g., citrus rootstock alemow, resistant to phytophthora (root rot \& gummosis) and in ber as rotundifolia impart vigorousness.

Table1. Methods of propagation of arid horticultural crops (vision ICAR-CIAH, 2030)

\begin{tabular}{|c|c|c|c|c|}
\hline \multirow[t]{2}{*}{ S.N. } & \multirow[t]{2}{*}{ Crop name } & \multicolumn{3}{|c|}{ Methods of propagation } \\
\hline & & Standardized & Commercial & Advance \\
\hline 1 & Acid lime & Seed, budding, Air layering & Seed & Budding \\
\hline 2 & Aonla & Budding & $\begin{array}{l}\text { T-budding/ } \\
\text { budding }\end{array}$ & Budding \\
\hline 3 & Bael & $\begin{array}{l}\text { Root cutting, budding, } \\
\text { layering }\end{array}$ & Patch budding & $\begin{array}{l}\text { Soft wood } \\
\text { grafting \& } \\
\text { budding }\end{array}$ \\
\hline 4 & Ber & $\begin{array}{l}\text { Budding }(\mathrm{T}, \mathrm{I}, \text { ring and } \\
\text { forkert })\end{array}$ & $\begin{array}{l}\text { In-situ budding (T- } \\
\text { budding) / Polytube } \\
\text { budding method }\end{array}$ & Budding \\
\hline
\end{tabular}




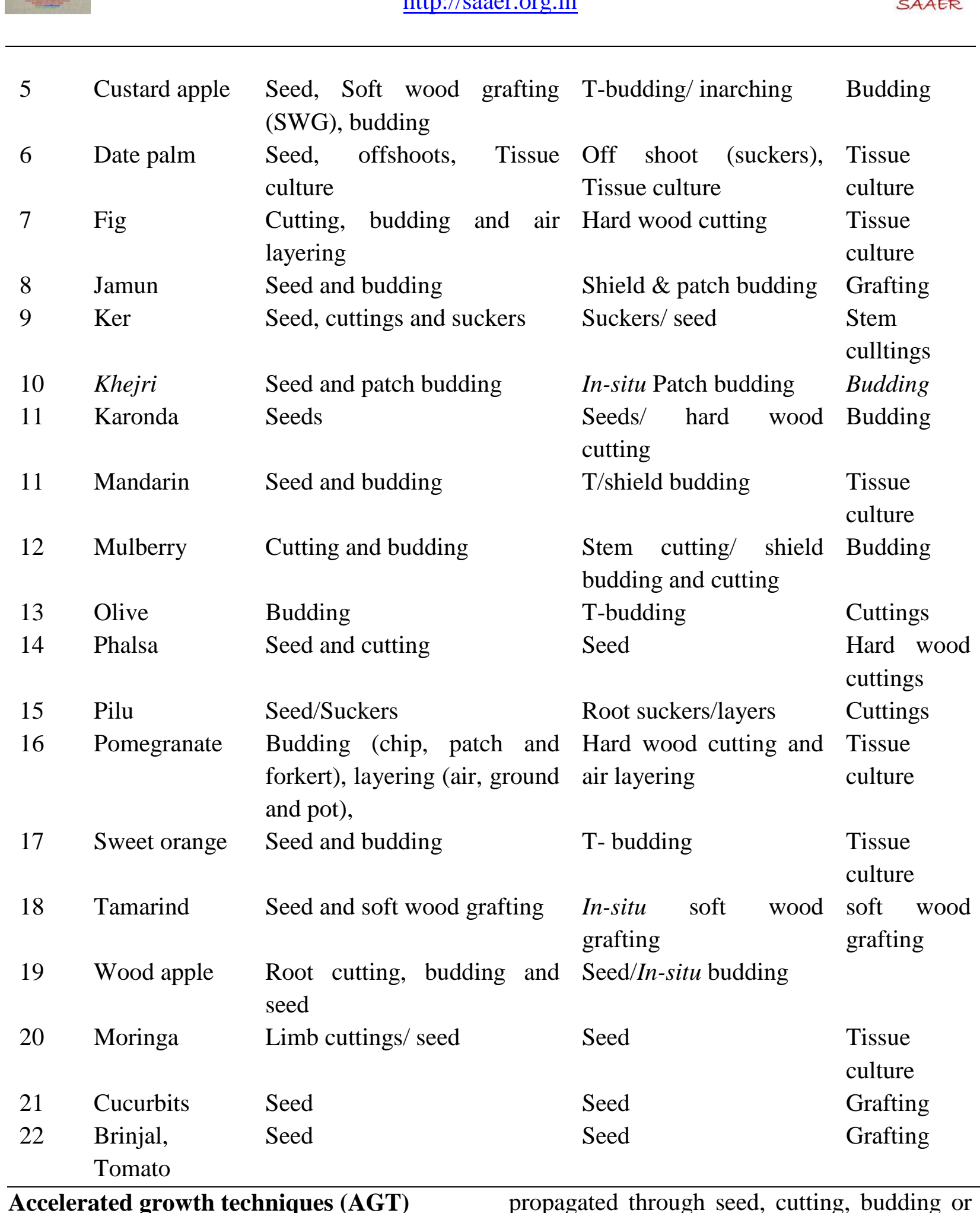

propagated through seed, cutting, budding or

Perennial fruit crops undergo cyclic growth and many species experienced dormancy during winters in order to speed up the growth and development of saplings grafting, a concept of accelerated growth system has become important aspect of commercial plant propagation to make available optimum size of saplings for field 
plantation within few months rather than years. Components of accelerated growth technique used in faster growth and development of citrus saplings propagated through soft wood cuttings (Singh et al. 2009) are given below:

AGT Protocol for citrus (Singh et al. 2009) Induction of rooting in cutting portrays (cutting size 10-15 cm) after one month

Transfer in poly bags of $4 \times 10$ ” size contains Sand +clay+ vermicompost $(2: 1: 1)$

Put into protected structures in a plastic trays filled with sand and FYM (3:1)

Programmed growth control throughout the growth period controlling using

- Light : 50000 lux

- Temperature : $30 \pm 2{ }^{\circ} \mathrm{C}$

- Mineral nutrient

: NA

- Water-humidity

: $60 \pm 5 \%$

- Growth regulators

: NA

- Interaction of PGPR of PGPR two : Application application at 15 days interval

- Growing media vermicompost $(2: 1: 1)$

- Competition weeding

- Pest : Sand +clay + spray of pesticides

: Regular

: Regular

Production of large rooted cutting plants (50$60 \mathrm{~cm}$ height) in 06 months age rather than years (More \& Singh 2008)

Acclimatization to natural condition for field plantation

\section{Management of plants after propagation}

The propagated plants need to be hardened. It is always better to harden them in the shade net houses or climate controlled houses. If these are not available then they need to be kept in semi-shade conditions, so that there is no mortality of plants when they are taken to the main field. Timely sprays for insects and diseases need to be given after ascertaining the cause. To maintain the plants in healthy condition, it is better to be given micro-nutrient sprays. However, it is also of paramount importance that the plants need to be labeled properly so that the variety is not mixed up (More et al. 2008).

\section{Low cost energy efficient hardening technology}

This technique include covering of pots by perforated poly ethylene bags, use of polyhouse or glasshouse equipped with fan/ pad and fogging/ misting devices, application growth retardant such as paclobutrazole or ancymidol have been reported to improve acclimatization of plantlets. However, these techniques are either inefficient or capital and energy intensive and not applicable to all agroecological conditions.

Looking into the inherent hardening problem of tissue culture plants, a three step low cost energy efficient hardening facility for tissue culture plants for arid agro ecosystem was developed at Central Institute for Arid Horticulture, Bikaner. In the present study, a three step plant hardening facility involving primary hardening in acclimatization hood made of plastic tray covered with polycarbonate sheet with ventilation device inside culture room for 7-10 days and subsequent transfer to evaporative cool chamber for 7-10 days thereafter acclimatization of plantlets either in shade house or low cost polyhouse (depending on 
ambient environment) equipped with insect proof plastic net, thatches of local grass intermittent fogging device. The first step of plant hardening achieved under and shaded by agronet of 50 per cent light acclimatization hood utilizing existing intensity. These three covers of cool chamber environmental controlled facilities of culture room of the laboratory without use of extra energy for creating favourable environmental conditions. In culture room, acclimatization hood found suitable to maintain $25-27^{0} \mathrm{C}$ temperature and relative humidity up to 90 per cent. Favourable environmental conditions such as $25-30^{\circ} \mathrm{C}$ temperature and $70-80$ per cent relative humidity were achieved during second step of hardening process under zero was found to regulate temperature and humidity inside the chamber significantly. Under third step of plant hardening, low cost polyhouse/ shade house with energy efficient intermittent fogging device (250 watts capacity) was used for further growth and development of plantlets in pots. Under this low cost three step hardening facility, acclimatization of tissue cultured plants of Cordya myxa, Capparis decidua and cactus pear (Opuntia ficus-indica) have been energy evaporative cool chamber by covering successfully achieved.

Table 3. Major environmental regime under three step hardening system

\begin{tabular}{|c|c|c|c|c|}
\hline $\begin{array}{c}\text { S. } \\
\text { No. }\end{array}$ & Steps of hardening & $\begin{array}{l}\text { Temperature } \\
\text { range } \\
\left({ }^{0} \mathrm{C}\right)\end{array}$ & $\begin{array}{c}\text { Relative } \\
\text { Humidity } \\
(\%)\end{array}$ & $\begin{array}{l}\text { Light } \\
\text { intensity } \\
\text { range (lux) }\end{array}$ \\
\hline 1 & $\begin{array}{l}\text { Acclimatization hood made of } \\
\text { polycarbonate sheet with ventilation device } \\
\text { kept inside culture room }\end{array}$ & $25 \pm 2$ & $75-95$ & $3000-5000$ \\
\hline 2 & $\begin{array}{l}\text { Evaporative cool chamber covered by } \\
\text { insect proof net, thatches of local grass and } \\
\text { shaded by agronet of } 50 \text { per cent light } \\
\text { intensity. }\end{array}$ & $25-30$ & $70-80$ & $5000-10000$ \\
\hline 3 & $\begin{array}{l}\text { Low cost polyhouse /shadehouse equipped } \\
\text { with intermittent fogging device ( } 250 \text { watts } \\
\text { capacity). }\end{array}$ & $25-35$ & $60-80$ & $10000-20000$ \\
\hline
\end{tabular}

Table 4. Potting substrate and their combination under different hardening steps

\begin{tabular}{llccccc}
\hline $\begin{array}{l}\text { S. } \\
\text { No. }\end{array}$ & Steps of hardening & $\begin{array}{c}\text { Vermiculite } \\
(\boldsymbol{\%})\end{array}$ & $\begin{array}{c}\text { Coco } \\
\text { peat } \\
(\boldsymbol{\%})\end{array}$ & $\begin{array}{c}\text { Perlite } \\
(\boldsymbol{\%})\end{array}$ & $\begin{array}{c}\text { Vermicompost } \\
(\boldsymbol{\%})\end{array}$ & $\begin{array}{c}\text { Soil } \\
\text { (sandy) } \\
(\%)\end{array}$ \\
\hline 1 & Acclimatization hood & 60 & 30 & 10 & - & - \\
2 & $\begin{array}{l}\text { Evaporative cool } \\
\text { chamber }\end{array}$ & 60 & - & - & 40 & - \\
3 & $\begin{array}{l}\text { Low cost polyhouse } \\
\text { /shadehouse }\end{array}$ & - & - & - & 30 & 70 \\
\hline
\end{tabular}


5. Saplings protection from insect-pest, diseases etc.:

- Follow strictly all good nursery practices with due consideration of plant protection, plant health, waste disposal, site cleaning and preventive measures time to time. A provision of indicator crop/cultivar planting with note down, which insect(s) affected first.

- Regular monitoring nursery at least twice a week with recording insect pest population particularly pay attention to sensitive species. Some selective insect traps are available but yellow, blue sticky traps can be used to identify pests like aphid, whiteflies, flies, thrips, leaf miners, scales insect etc., apart from that pheromone traps a good monitoring technique.

- It is necessary to maintain vigorous, healthy plants by using proper cultural and management practices to provide natural resistance to plants. Heavily insect infested or injured plants should be destroyed as earliest possible (Sarolia et al. 2021).

- Sterilized/ pasteurized potting mixture should be used in primary and secondary nurseries.

- Remove off type plants and too long tap root should be cut.

- Seedlings should be treated with Ridomil @ $2.75 \mathrm{~g}$ or Copper oxi chloride @ $2.5 \mathrm{~g} / 1$ water at the time for transplanting in secondary nursery.

- Budding/grafting is done at about $20 \mathrm{~cm}$ height from ground. With using all material should be sterilized.

- Regular recommended plant protection measures should be followed to control insect, pest and diseases (Anonymous 2010; Singh et al. 2009).

Table 5. List of major plant protection formulations (www.agropedia)

\begin{tabular}{|c|c|c|c|c|}
\hline $\begin{array}{l}\text { S. } \\
\text { No }\end{array}$ & Technical name & Trade name & Dose & $\begin{array}{l}\text { Target pest/ } \\
\text { organisms }\end{array}$ \\
\hline 1 & Imidacloprid $17.8 \mathrm{SL}$ & $\begin{array}{l}\text { Confidor 200SL } \\
\text { Gaucho 70WP } \\
\text { Imidacloprid } \\
30.5 \mathrm{SC}\end{array}$ & $\begin{array}{l}2.8 \mathrm{ml} \text { in } 10 \text { liter } \\
\text { water or } 10 \mathrm{~g} / \mathrm{kg} \text { seed }\end{array}$ & $\begin{array}{l}\text { All kind of sucking } \\
\text { pests } \\
\text { Termite control }\end{array}$ \\
\hline 2 & Profenofos50EC & Curacron $50 \mathrm{EC}$ & $\begin{array}{l}0.75 \mathrm{ml} \text { in } 15 \text { litre } \\
\text { water }\end{array}$ & Thrips, mites \\
\hline 3 & Carbosulfan 25\%EC & Marshal & $0.5-1.0 \mathrm{ml} \mathrm{l}^{-1}$ & $\begin{array}{l}\text { Sucking pest \& } \\
\text { Caterpillar }\end{array}$ \\
\hline 4 & $\begin{array}{l}\text { Fipronil } \\
8 \mathrm{WG}\end{array}$ & $\begin{array}{ll}\text { Regent } 8 & \mathrm{Wg} \\
\text { (Termidor) } & \end{array}$ & $40-75 \mathrm{~g}$ a.i ha ${ }^{-1}$ & $\begin{array}{l}\text { Termite, thrip, weevil } \\
\text { and moth }\end{array}$ \\
\hline 5 & Abamectin & $\begin{array}{l}\text { Vertimec } \\
1.95 \mathrm{WW}\end{array}$ & 0.25 to $0.5 \mathrm{ml}$ litre ${ }^{-1}$ & Mite and leaf miners \\
\hline 6 & Propargite $75 \%$ EC & $\begin{array}{l}\text { Omit, comit, } \\
\text { ornamite }\end{array}$ & $750-1500 \mathrm{ml} \mathrm{ha}{ }^{-1}$ & Acaricide \\
\hline
\end{tabular}




\begin{tabular}{|c|c|c|c|c|}
\hline 7 & Malathion 50EC & Cythion, $5 \%$ dust & $\begin{array}{l}\text { 1-1.5ml litre } \text { li }^{-1} \text { 500- } \\
750 \text { a.i. } \text { ha }^{-1} \text { (dust) }\end{array}$ & Contact insecticide \\
\hline 8 & $\begin{array}{l}\text { Indoxicarb } \\
\text { EC }\end{array}$ & Indocab, Advion & 30-75gm a.i/Ha & $\begin{array}{l}\text { Systemic \& Contact } \\
\text { action in lepidopteron } \\
\text { insect }\end{array}$ \\
\hline 9 & $\begin{array}{l}\text { Thiomethexam } \\
\text { WG }\end{array}$ & Actara, ariva & $4 \mathrm{~g} / 15$ litre & Systemic \\
\hline 10 & Dimethoate30EC & $\begin{array}{l}\text { Rogor, Rallies } \\
\text { India } \\
\text { Mumbai }\end{array}$ & $\begin{array}{llr}594-1650 & \mathrm{ml} & \text { per } \\
500-1000 & \text { litre } & \text { of } \\
\text { water } & & \end{array}$ & $\begin{array}{l}\text { Sucking and } \\
\text { caterpillar insects }\end{array}$ \\
\hline 11 & Carbofuran & $\begin{array}{l}\text { Furadon3G, } \\
50 \mathrm{SP}\end{array}$ & $\begin{array}{l}250-2000 \mathrm{~g} \text { a.i. or } \\
8.3-66 \mathrm{~kg} \mathrm{ha}^{-1}\end{array}$ & $\begin{array}{l}\text { Contact \& systemic } \\
\text { against nematodes, } \\
\text { white grub, etc. }\end{array}$ \\
\hline 12 & $\begin{array}{l}\text { Fluebendemide- } \\
20 \% \mathrm{WG}\end{array}$ & Fluton, & $100 \mathrm{ml} / 500$ litre & $\begin{array}{l}\text { Lepidopteron insect, } \\
\text { Borer }\end{array}$ \\
\hline 13 & Spinosad & $\begin{array}{l}\text { Spintor, } \\
\text { Conserve, } \\
\text { Success }\end{array}$ & $0.4 \mathrm{ml} /$ lotre & Fruit fly and borer \\
\hline 14 & $\begin{array}{l}\text { Verticillium } \\
1.15 \mathrm{WP}\end{array}$ & Bio- catch & $3 \mathrm{~g}$ Green & $\begin{array}{l}\text { Aphids, whiteflies, } \\
\text { and thrips }\end{array}$ \\
\hline 15 & $\begin{array}{l}\text { Neem(Aza } \\
\text { ppm) }\end{array}$ & $\begin{array}{l}\text { Neemarin, } \\
\text { Neemazol T/S }\end{array}$ & $1 \mathrm{ml}$ Green & $\begin{array}{l}\text { Termite, sucking in } \\
\text { sect }\end{array}$ \\
\hline 16 & $\begin{array}{l}\text { Baccilus } \\
\text { thuringiencis 5WP }\end{array}$ & $\begin{array}{l}\text { Biolep, Halt, } \\
\text { Minchu }\end{array}$ & $1.00 \mathrm{~g}$ & Lepidopteron insects \\
\hline
\end{tabular}

\section{Saplings quality assurance and} marketing strategies:

National horticulture board now recognize and accredit nursery and provide star rating by inspection thoroughly based on determine the quality of planting material. Online application form and attach the required documents (refer checklist) required as part of the application and submit the application to National Horticulture Board (NHB) for accreditation (www.nhb.com). NHB also allotted the star rating on the basis of performance and quality services details as outstanding (5 star), excellent (4 star), very good (3 star), good (2 star) and satisfactory (1 star). Quality standards depending upon kind of the crops, but healthy, vigorous, proportionate size saplings propagated with standard protocol is desirable eg. Grafted plants should be healthy, vigorous and equal in size of scion - rootstock, proper in shoot: root ratio, free from disease, weed and insectpests and proper in morphological standard of scion according to varieties and species (http://tmnehs.gov.in and Srivastav et al. 2015). Scion height in khejri and ber should not be less than 20 and $30 \mathrm{~cm}$, respectively in 
plantable saplings (Sarolia et al. 2018, Mishra et al. 2020).

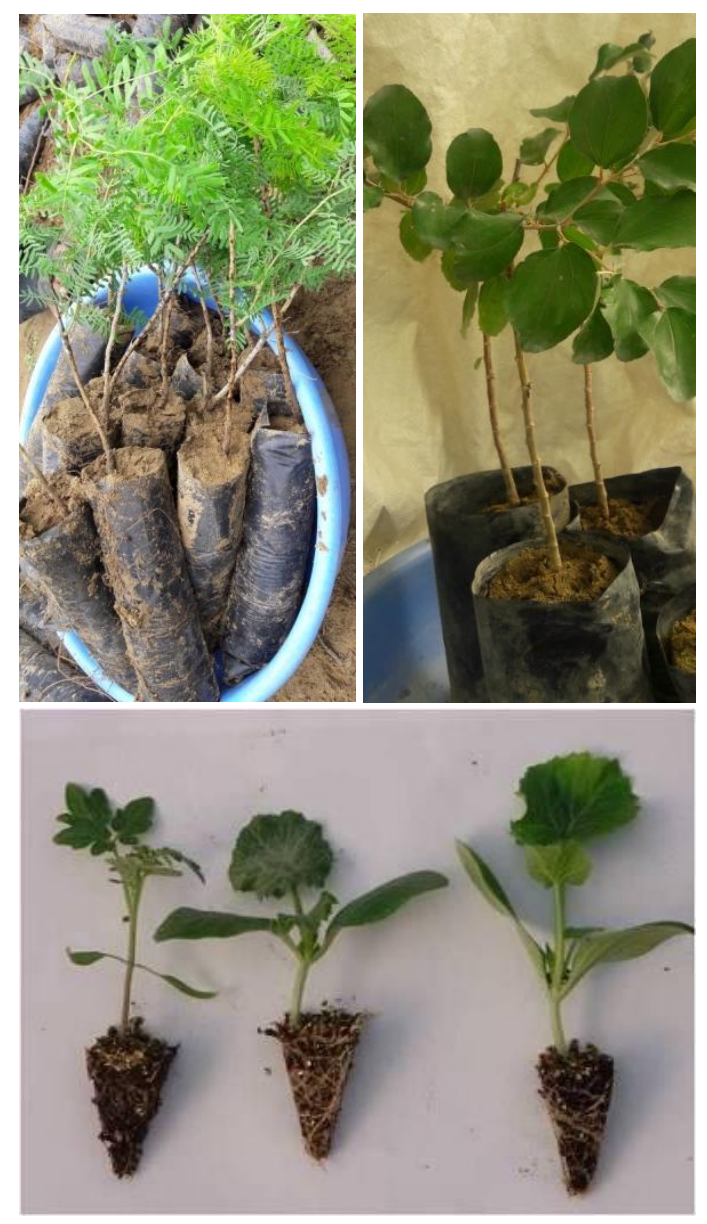

Quality saplings in polybags and plug tray Marketing of nursery plants is a problem in India as there is no proper marketing system in our country. Nurserymen do not get good price from their products because the price in the market depends on demand and supply of the products. Nurserymen should give emphasis on the following points to get higher price (Singh et al. 2017) from his products.

- Nurserymen should give emphasis on production and quality of the materials.

- Plants to be sold should be uniform in size.
- Before packing, grading of the plant should be done.

- Packing of the nursery plants should be done properly and the packing materials look appealing.

- Plants that are to be sold should be healthy, and free from pests and diseases. They should also have attractive foliage.

- Nursery grown plants should be nicely labeled and displayed attractively at the sale counter.

- Plants should be carefully handled during transport to avoid damage to the materials. It will also help plants to reach in the hands of the customers in a better condition. This will help to fetch better price in the market.

- The nursery should supply the catalogue or pamphlets containing the detailed information for planting, handling and management of the plants offered for sale.

\section{Disposal and Record management}

Disposal of produce also requires skillful management otherwise, whole efforts are futile. It requires timely action so that users may get quality planting materials at proper time and at the same time, producer may gain the desired returns. Sometimes, planting materials remain unsold if they are produced delayed in the season. Further, keeping them for longer period in the nursery may not only involve additional expenditure but the quality of planting materials reduced due to coiling of the roots and overgrowth of plants. The nursery manager must contact the users and even he should do advance booking. The planting materials raised either in beds or in polybags should be lifted properly. 
Unwanted foliage should be removed to minimize transpiration losses. They should be graded based on size, age, vigour etc. and packed in such a way that roots remain moist. For wrapping of the planting stocks, grasses, straw, perforated polythene, gunny bags, moss grass etc. are generally used as packing materials. Now a day's wooden or perforated paper boxes and plastic tray are used for long distance transit. There should be minimum time gap between lifting of the stock from the nursery and planting at desired site. To avoid exposure to sun, the planting materials should be lifted from the nursery in the evening and planted on the next day.

Records of all purchases (seed, chemicals, media, etc.), observation of data (sowing, germination dates and germination per cent, growth, etc.), labor engagement and attendance, sales, pest and disease outbreaks, permanent and temporary stocks (including species wise seedling stocks) and movement register are required to be maintained up to date. Various records of expenditure and income are recorded in different book viz., purchase book, sales book, ledger, cash book, dispatch register, etc. It is advisable to maintain books of accounts for the following reasons:

1. They provide up-to-date nursery business information and guideline for planning

2. They help to analyze the performance of the nursery activity

\section{Conclusion}

The nursery aim is to generate quality planting material. Standard protocol and Good Nursery Practices (GNPs) have to be followed for the production of genuine material at a reasonable price. Assurance of quality of saplings through accreditation and star rating enhances the creditability of the nursery. Unless uniform planting material of the desired type is available, increased productivity levels are difficult to be achieved. Hence, a fusion of technologies for raising plantlets has to be encouraged. Properly labeled genuine quality planting material not only survive well in field condition but also increases trustworthiness and income of the organization and promotion of arid horticulture component in this region. Thus, quality saplings production in arid horticultural crops under open as well as advanced nurseries definitely will play an important role in employment generation and remunerative enterprise in the changing national scenario

\section{References}

Anonymous 2010. Disease management In: Annual Report, All India Co-ordinate Research Project on Arid Zone Fruits. pp. 135- 144.

Anonymous 2021. Retrieved from https://agritimes.co.in/horticulture/ fruits/ total-horticulture-productionpegged-at-326-58-mt-in-the-firstadvance-estimates-of-2020-21

Bhardwaj RL \& Sarolia DK. 2011. Modern Nursery Management, Agrobios (India) (ISBN-978-81-7754-434-3): 1-403.

Hartmann HT, Kester DE, Davies FT \& Geneve RL. 2002. Plant Propagation Principles and Practices (seventh ed.), Prentice Hall International, New Delhi. 170-175 pp

Mbora A, Lilleso JPB \& Jamnadass R. 2008. Good nursery practices: A simple guide 
(ISBN: 978-92-9059-235-8). Nairobi. The World Agroforestry Centre: 36.

Mishra DS, Singh S, AK Singh, VV Appa Rao \& DK Sarolia. 2020. Techniques of orchard establishment in arid and semiarid regions. Journal of Agriculture and Ecology, 10: 22-35.

More TA \& Singh D. 2008. Zero day juvenility in planting material of fruit crops ICAR News Letter, (Jan-Mar).

More TA, Singh D, Awasthi OP, Samadia DK \& Singh IS. 2008. Hi-Tech production of Arid Horticulture, ICAR-CIAH, Bikaner pp. 1-515.

National Horticulture Board, Ministry of Agriculture \& Farmer's Welfare Website www.nhb.gov.in/nursery accreditation format. Retrieved from http://nhb.gov.in/PDFViwer.aspx?enc=3 ZOO8K5CzcdC/Yq6HcdlxGRDiruRWEIDuJ sDa1K0GDw.

Ratha Krishnan P, Rajwant K Kalia, Tewari JC \& Roy M M. 2014. Plant Nursery Management: Principles and Practices. Central Arid Zone Research Institute, Jodhpur, 40 p.

Sarolia DK \& Meena RK. 2018.Nursery raising for livelihood security. Indian Horticulture (Special issue Sep.- Oct.): 78-81.

Sarolia DK, Bhardwaj RL, Singh V \& Kaushik RA. 2013. Practical manual on "Production Technology of Fruit Crops", Department of Horticulture, Rajasthan College of Agriculture, MPUAT, Udaipur (Raj.): 1-96.

Sarolia DK, Meena RK, Kumar Ramesh, Singh PP \& Gora JS. 2018. Mass multiplication of quality planting material in horticulture crops. In: Horticulture in arid and semi arid region (Edt.: Jatav M.K., Saroj P.L. and Sharma B.D.). New India Publishing Agency, New Delhi: 305-314pp.

Sarolia DK, Samadia DK, Choudhary BR \& Singh D. 2018. Production of quality seed and planting materials. CIAH/Tech./Pub. No. 75, Page No. 38 ICAR-Central Institute for Arid Horticulture, Bikaner (Indian): 1-38.

Sarolia DK, Meena RK \& Kumar L. 2021. Insect free planting material through nursery management. In: Pest Management in Dry land Horticultural crops (Edt. SM Haldhar \& SK Maheshweri). Biotech Books, New Delhi :211-216.

Sharma RR and Srivastav M. 2004. Plant Propagation and Nursery Management. Published by International Book Distributing Company, p. 408.

Singh AP. 2009. Field Problems of Fruit Crops. Published by Additional Director of Communication, PAU, Ludhiana, p. 258.

Singh D, More TA, Samadia DK, Singh UV, Choudhary ML \& Ramniwas. 2008. Mist propagation of Karonda - Effect of IBA and media composition on root formation In book of abstracts of National seminar on opportunities and challenges of arid horticulture crops for nutrition and livelihood held at ICARCIAH, Bikaner (March 18-19),: pp.8-9

Singh D, More TA, Singh RS, Awasthi OP \& Singh UV. 2008. Chilling injury in nursery saplings and its management 
under arid ecosystem. In book of abstracts of National seminar on opportunities and challenges of arid horticulture crops for nutrition and livelihood held at ICAR-CIAH, Bikaner (March 18-19).

Singh D, Singh UV, More TA \& Awasthi OP. 2009. Hi-tech propagation of arid fruit crops. CIAH/Tech./Pub. No. 36, Page No. 26 ICAR-Central Institute for Arid Horticulture, Bikaner (Indian): 1-36.

Singh D. \& More TA. 2008. Hi-tech Propagation of Arid Fruit Crops. In: $\mathrm{Hi}$ tech Production of Arid Horticulture (Compiled \& Edited by TA More D Singh, OP Awasthi, DK Samadia \& IS Singh). ICAR-CIAH? RES/PUB/No.33: pp.176-190.

Singh RR, Meena LK \& Singh Paramveer 2017. High Tech Nursery Management in Horticultural Crops: A Way for Enhancing Income. Int. J. Curr. Microbiol. App. Sci., 6(6): 3162-3172.
Srivastav M., Singh SK, Verma MK and Prakash Jai, 2015. Quality Planting Material in Fruit Crops: GAP and Certification Standards (https:// www.researchgate.net/profile/M-KVerma/publication/282367651_Qualit_p lanting_material_in_fruit_crops_GAP_a nd_Certification_standards /links/ 560f16f908ae4833751787a3/Qualityplanting-material-in-fruit-crops-GAPand-Certification-standards.pdf

Surya Gunjal (COPI, NAIP e- publication). 2012. Resource book on horticulture nursery management, NAIP, ICAR: 1-268. www.fdcm. nic.in/PDF/ Horticulture \%20plant\% 20 nursery. pdf .

Vision-2030, ICAR-CIAH. 2011. Mother plants and propagation techniques standardization: p12.

www.agropedia.iitk.ac.in/content/nurserymanagement-vegetables. 